\title{
Green Synthesis of New Tetra Schiff Bases and Bis-Azo Bis-Schiff Bases Derived from 2,6-Diaminopyridine as Promising Photosensitizers
}

\author{
Nihad I. Taha, Nashwan 0. Tapabashi, Marwa N. El-Subeyhi \\ Department of Chemistry, College of Science, University of Kirkuk, Kirkuk, Iraq \\ Email: nihad_ismael@yahoo.com
}

How to cite this paper: Taha, N.I., Tapabashi, N.O. and El-Subeyhi, M.N. (2018) Green Synthesis of New Tetra Schiff Bases and Bis-Azo Bis-Schiff Bases Derived from 2,6-Diaminopyridine as Promising Photosensitizers. International Journal of Organic Chemistry, 8, 309-318.

https://doi.org/10.4236/ijoc.2018.83023

Received: June 21, 2018

Accepted: August 17, 2018

Published: August 20, 2018

Copyright $\odot 2018$ by authors and Scientific Research Publishing Inc. This work is licensed under the Creative Commons Attribution International License (CC BY 4.0).

http://creativecommons.org/licenses/by/4.0/

\begin{abstract}
Nine new tetra Schiff bases $\left(M_{2}-M_{9}\right)$ were prepared in moderate yields via the condensation of different aromatic amines and bis-Schiff base $\left(M_{1}\right)$ in microwave synthesizer. Also five new azo-Schiff bases $\left(M_{16}-M_{20}\right)$ were prepared by the condensation of $\left(M_{1}\right)$ with the azo-salicylaldehyde $\left(M_{11}-M_{15}\right)$ using the same method. The green synthesis by microwave irradiation was chosen as route due to its novelty, cleanliness, efficiency, time and solvent saving properties compared with the conventional methods which lack these advantages; such as time consume and wasting environment polluting organic solvents to achieve the same efficiency in synthesis. The prepared compounds which are believed by us to be competent as photosensitizers in photochemical systems were identified by IR and NMR spectroscopy besides elemental analysis.
\end{abstract}

\section{Keywords}

Schiff Base, Azo-Schiff Base, 2,6-Diaminopyridine, Azo-Salicyladehyde, Photosensitizer

\section{Introduction}

Schiff bases, by containing the azomethine group $(\mathrm{C}=\mathrm{N})$ as the central structural form, have been the subject of prevalent research in the various fields of industry, pharmaceuticals and the synthesis of biologically active organic compounds [1] [2] [3] [4]; besides corrosion inhibitors [5]. Recently Schiff bases became an important class of ligands in coordination chemistry [6]; Metal complexes the- 
reof have shown attractive properties such as antibacterial behavior [7] [8] and exhibit interesting magnetic characteristics as well as catalytic oxidation [9]. Various methods and routes have been developed for the synthesis of Schiff bases such as reflux in ethanolic solution, stirring, grinding in mortar, besides microwave irradiation methods [10]. The last one has received increasing interest from researchers [11] [12] [13]. Synthesis of some Schiff bases was reported in aqueous medium as a green alternative approach [14]. Azo-Schiff compounds are a new class of chemical compounds that are receiving increasing concern in scientific research [15]-[21]. In the present days, these derivatives display remarkable applications in each and every field [22]-[30]. An earlier study showed that the incorporation of Schiff bases into azo compound structure resulted in enhanced photostability property of the prepared azo-Schiff compounds compared with the azo precursors; whereas the azo linkage, as chromophor, assists in extending the absorption of the resulted compound to the longer waves of the solar spectrum [30]. This acquired property enables them to be potential photosensitizers in photochemical systems as a part of the recent strategy for environmentally benign solar energy conversion methods [31] [32] [33]. The aim of this work is to prepare some new tetra-Schiff bases and azo-Schiff bases as a part of a comprehensive plane to develop new photosensitizers adapting the advantageous concept of green methods in synthesis [6] [12].

\section{Experimental}

\subsection{Materials and Methods}

All chemicals were obtained from sigma-Aldrich, Merck, and Scharlau, and used without further purification. Melting points were determined using a calibrated thermometer by electro thermal melting point apparatus Stuart-SMP11; and were uncorrected. Elemental analyses were performed by department of chemistry, Ibn-al Haitham College of Education, University of Baghdad, Baghdad/ Iraq. IR spectra were recorded in Ibn-al Haitham college of Education, University of Baghdad as $\mathrm{KBr}$ discs on a Nicolet 100 FT-IR spectrophotometer. Uv-visible spectra were recorded on (UV-VIS) Spectrophotometer-PG $+92 .{ }^{1} \mathrm{H}$ NMR spectra were recorded as solutions in DMSO on a NM Ready 60 pro, chemical shifts were referenced to Tetramethylsilane in the same university. Microwave irradiations were carried out in microwave synthesizer, BoMann.

\subsection{Synthesis of}

6,6'-\{[1,4-Phenylenebis(methanylylidene)]bis(azanylylidene) $\}$ bis(pyridine-2-amine) ( $\left.\mathbf{M}_{1}\right)$, (Microwave Method)

A mixture of ( $2 \mathrm{mmol}, 0.218 \mathrm{~g}$ ) 2,6-Diaminopyridine and ( $1 \mathrm{mmol}, 0.134 \mathrm{gm})$ of Terphthaldehyde was finely powdered in a porcelain mortar and then transferred to $(50 \mathrm{~mL})$ sized beaker to which (6 drops) of glacial acetic acid and (4 drops) of absolute ethanol were added. The contents of the beaker were subjected to microwave irradiation at $200 \mathrm{~W}$ (low power) for about 10 minutes. 
Progress of the reaction was monitored by TLC. The yellow solid product obtained was washed with petroleum ether $(50-60)^{\circ} \mathrm{C}$ grade, followed by hot ethanol and left to dry in room temperature for $(24 \mathrm{hrs}$.). The title solid powder has the yield (65\%); m.p. $258^{\circ} \mathrm{C}-260^{\circ} \mathrm{C}$; IR $(\mathrm{KBr})\left(\mathrm{cm}^{-1}\right): 3373,3150(\mathrm{~N}-\mathrm{H}$, asy, sym), $3000(\mathrm{C}-\mathrm{H}$ aromatic), $1602(\mathrm{C}=\mathrm{N}), 1500(\mathrm{C}=\mathrm{C}$ aromatic). UV-vis $(\mathrm{nm})$ : $248,325,390$.

\subsection{General Procedure for the Synthesis of Tetra SCHIFF Bases (Green Route Method)}

The same procedure which was used in preparing the precursor $\mathrm{M}_{1}$; was applied in synthesizing the following compounds by mixing ( $1 \mathrm{mmol}, 0.316 \mathrm{gm})$ of $\mathrm{M}_{1}$ with $(2 \mathrm{mmol})$ of different aldehydes.

1,1'-(bis 1,4-phenylene)bis $\{\mathrm{N}$-[6-(benzylideneamino)pyridine-2-yl] methanimine $\left(\mathrm{M}_{2}\right)$ : m.p. $280^{\circ} \mathrm{C}-284^{\circ} \mathrm{C}, 48 \%$; IR $\left(\mathrm{KBr}, \mathrm{cm}^{-1}\right): 3030$ (C-H aromatic), $1601(\mathrm{C}=\mathrm{N}), 1599$ (C=C aromatic). UV-vis (nm): 245, 320, 395. Anal. Calcd $\left(\mathrm{C}_{32} \mathrm{H}_{24} \mathrm{~N}_{6}\right): \mathrm{C}, 78.03 ; \mathrm{H}, 4.91 ; \mathrm{N}, 17.06$. Found: $\mathrm{C}, 77.46 ; \mathrm{H}, 4.92 ; \mathrm{N}, 17.97$.

4,4'-((((1,4-phenylenebis(methanylylidene))bis(azanylylidene))bis(pyridine-6,2diyl))bis(azanylylidene))bis(methanylylidene))bis(N,N-dimethylanoline) $\left(\mathrm{M}_{3}\right)$ : m. p. $242^{\circ} \mathrm{C}-246^{\circ} \mathrm{C}, 63 \%$; IR $\left(\mathrm{KBr}, \mathrm{cm}^{-1}\right): 3100(\mathrm{C}-\mathrm{H}$ aromatic), $1599(\mathrm{C}=\mathrm{N})$, 1590 ( $\mathrm{C}=\mathrm{C}$ aromatic), 2853 (C-H aliphatic). UV-vis (nm): 248, 310, 405. Anal. Calcd. $\left(\mathrm{C}_{36} \mathrm{H}_{34} \mathrm{~N}_{8}\right)$ : C 74.72; H, 5.92; N, 19.36. Found: C 74.81; H, 5.07; N, 20.00.

1,1'-(1,4-phenylene)bis $\{\mathrm{N}$-[6-((4-methoxybenzylidene)amino)pyridine-2-yl] methanimine $\left(\mathrm{M}_{4}\right)$ : m.p. $245^{\circ} \mathrm{C}-248^{\circ} \mathrm{C}, 56 \%$; IR $\left(\mathrm{KBr}, \mathrm{cm}^{-1}\right): 3046(\mathrm{C}-\mathrm{H}$ aromatic), $1602(\mathrm{C}=\mathrm{N}), 1450(\mathrm{C}=\mathrm{C}$ aromatic), 2849 (C-H aliphatic). UV-vis (nm): 254, 300, 410 .

1,1'-(1,4-phenylene)bis $\{\mathrm{N}-[6-((4-$ nitrobenzylidene)amino)pyridin-2-yl] methanimine $\left(\mathrm{M}_{5}\right)$ : m.p. $262^{\circ} \mathrm{C}-268^{\circ} \mathrm{C}, 58 \%$; IR $\left(\mathrm{KBr}, \mathrm{cm}^{-1}\right): 3109$ (C-H aromatic), $1597(\mathrm{C}=\mathrm{N}), 1584$ ( $\mathrm{C}=\mathrm{C}$ aromatic), 1514, 1344 (asy, sy $\mathrm{NO}_{2}$ ). UV-vis (nm): 252, 310, 420. Anal. Calcd. $\left(\mathrm{C}_{32} \mathrm{H}_{22} \mathrm{~N}_{8} \mathrm{O}_{4}\right)$ : C, 65.97; H, 3.81; N, 19.23. Found: C, 65.28; $\mathrm{H}, 3.86 ; \mathrm{N}, 19.55$.

2-(((6-)(4-(((6-((2-chlorobenzylidene)amino)pyridine-2-yl)imino)methyl)ben zylidene) amino)pyridine-2-yl)imino)methyl)phenol $\left(\mathrm{M}_{6}\right)$ : m.p. $240^{\circ} \mathrm{C}-242^{\circ} \mathrm{C}$, 60\%; IR ( $\left.\mathrm{KBr}, \mathrm{cm}^{-1}\right): 3057$ (C-H aromatic), $1589(\mathrm{C}=\mathrm{N}), 1449(\mathrm{C}=\mathrm{C}$ aromatic), 754 (C-Cl). UV-vis (nm): 250, 325, 395.

2-2'((((1,4-phenylenebis(methanylylidene))bis(azanylylidene))bis(pyridine-6, 2-diyl))bis(azanylylidene))bis(methanylylidene)diphenol $\left(\mathrm{M}_{7}\right)$ : m.p. $280^{\circ} \mathrm{C}$ $284^{\circ} \mathrm{C}, 42 \%$; IR $\left(\mathrm{KBr}, \mathrm{cm}^{-1}\right)$ : $3359(\mathrm{O}-\mathrm{H}), 3051(\mathrm{C}-\mathrm{H}$ aromatic), $1603(\mathrm{C}=\mathrm{N})$, $1481(\mathrm{C}=\mathrm{C}$ aromatic), 1275 (C-O). UV-vis (nm): 245, 308, 409. Anal. Calcd. $\left(\mathrm{C}_{32} \mathrm{H}_{24} \mathrm{~N}_{6} \mathrm{O}_{2}\right): 73.27 ; \mathrm{H}, 4.61 ; \mathrm{N}, 16.02$. Found: C, 73.05; H, 5.24; N, 17.03 .

4-4'((((1,4-phenylenebis(methanylylidene))bis(azanylylidene))bis(pyridine-6, 2-diyl))bis(azanylylidene))bis(methanylylidene)diphenol $\left(\mathrm{M}_{8}\right)$ : m.p. $236^{\circ} \mathrm{C}$ $240^{\circ} \mathrm{C}, 44 \%$; IR $\left(\mathrm{KBr}, \mathrm{cm}^{-1}\right): 3342(\mathrm{O}-\mathrm{H}), 3054(\mathrm{C}-\mathrm{H}$ aromatic), $1602(\mathrm{C}=\mathrm{N})$, 1450 (C=C aromatic), 1275 (C-O). UV-vis (nm): 248, 287, 412. 
1,1'-(1,4-phenylene)bis\{N-[6-((furan-ylmethylene)amino)pyridine-2-yl] methanimine $\left(\mathrm{M}_{9}\right)$ : m.p. $235^{\circ} \mathrm{C}-238^{\circ} \mathrm{C}, 73 \%$; IR $\left(\mathrm{KBr}, \mathrm{cm}^{-1}\right): 3107$ (C-H aromatic), $1602(\mathrm{C}=\mathrm{N}), 1494$ (C=C aromatic), 1213 (C-O). UV-vis (nm): 248, 308, 400.

N,N'-(((1,4-phenylenebis(methanylidene))bis)azanylyidene))bis(pyridine-6,2diyl))bis(3-phenylprop-2-en-1-imine) $\left(\mathrm{M}_{10}\right)$ : m.p. $252^{\circ} \mathrm{C}-254^{\circ} \mathrm{C}, 40 \%$; IR $(\mathrm{KBr}$, $\mathrm{cm}^{-1}$ ): 3105 (C-H aromatic), 3060 (C-H olefinic). UV-vis (nm): 251, 308, 401.

\subsection{Preparation of Azo-Salicylaldehydes $\left(M_{13}, M_{15}\right)$, Conventional Method [23]}

Azo-coupled salicylaldehyde precursors $\left(M_{11}-M_{15}\right)$ were prepared according to the well-known procedure [18]. Salicylaldehyde $(10 \mathrm{mmol})$ was dissolved in water $(20 \mathrm{ml})$ containing $(10 \mathrm{mmol})$ of Sodium Hydroxide and $(40 \mathrm{mmol})$ of Sodium Carbonate during $30 \mathrm{~min}$ at $0^{\circ} \mathrm{C}$. The result was added slowly to a solution of Diazonium Chloride $(10 \mathrm{mmol})$ in water at $0^{\circ} \mathrm{C}-5^{\circ} \mathrm{C}$. The reaction mixture was stirred for $(1 \mathrm{hr})$ at $0^{\circ} \mathrm{C}$ and then left to warm slowly to room temperature. The product was filtrated and washed with $100 \mathrm{ml}$ of $\mathrm{NaCl}$ solution (10\%) under vacuum. The collected solid was dried under vacuum at $80^{\circ} \mathrm{C}$ overnight.

5-[(chlorophenyl)diazenyl]-2-hydroxybenzaldehyde $\left(\mathrm{M}_{13}\right)$ : m.p. $176^{\circ} \mathrm{C}$ $178^{\circ} \mathrm{C}, 90 \%$; IR ( $\left.\mathrm{KBr}, \mathrm{cm}^{-1}\right): 3220(\mathrm{OH}), 3022(\mathrm{C}-\mathrm{H}$ aromatic), $1666(\mathrm{C}=0), 1479$ $(\mathrm{N}=\mathrm{N})$. UV-vis (nm): 253, 333, 414.

Sodium 4-[(3-formyl-4-hydroxyphenyl)diazenyl]benzenesulfonate $\left(M_{15}\right)$ : m.p. $260^{\circ} \mathrm{C}-263^{\circ} \mathrm{C}, 85 \%$; IR $\left(\mathrm{KBr}, \mathrm{cm}^{-1}\right): 3280(\mathrm{OH}), 3040$ (C-H aromatic), 1660 $(\mathrm{C}=0), 1433(\mathrm{~N}=\mathrm{N}) . \mathrm{UV}$-vis $(\mathrm{nm}): 250,320,419$.

\subsection{General Procedure for the Synthesis of Azo-Schiff Bases (Microwave Method)}

A mixture of ( $1 \mathrm{mmol}, 0.316 \mathrm{~g}) \mathrm{M}_{1}$ and $(2 \mathrm{mmol})$ of $\mathrm{M}_{11}-\mathrm{M}_{15}$ separately was finely grinded in a porcelain mortar. The contents were placed in $(50 \mathrm{~mL})$ beaker moistened with ( 3 - 4 drops) of glacial acetic acid and ( $1-2$ drops) of absolute ethanol and exposed to microwave irradiation at $200 \mathrm{~W}$ (low power). Monitoring the reaction by TLC, showed that (5) minutes of irradiation was enough to complete it. The resulted solid products were washed with petroleum ether (50 $60)^{\circ} \mathrm{C}$ grade and hot ethanol and left to dry in ambient temperature for (24 hrs).

2,2'(((((1,4-phenylenebis(methanylylidene))bis(azanylylidene))bis(pyridine-6,2diyl))bis(azanylylidene))bis(methanylylidene))bis(4-(phenyldiazenyl)phenol) $\left(\mathrm{M}_{16}\right)$ : m.p. $233^{\circ} \mathrm{C}-236^{\circ} \mathrm{C}$ dec., 59\%; IR $\left(\mathrm{KBr}, \mathrm{cm}^{-1}\right)$ : $3361(\mathrm{O}-\mathrm{H}), 3057(\mathrm{C}-\mathrm{H}$ aromatic), $1601(\mathrm{C}=\mathrm{N}), 1479(\mathrm{C}=\mathrm{C}$ aromatic), $1454(\mathrm{~N}=\mathrm{N})$. UV-vis $(\mathrm{nm}): 268$, 345, 422. Anal. Calcd. $\left(\mathrm{C}_{44} \mathrm{H}_{32} \mathrm{~N}_{10} \mathrm{O}_{2}\right): \mathrm{C}, 72.12 ; \mathrm{H}, 4.40 ; \mathrm{N}, 19.11$. Found: $\mathrm{C}$, 72.98; H, 5.09; N, 19.44 .

2,2'((((1,4-phenylenebis(methanylylidene))bis(azanylylidene))bis(pyridine-6,2diyl))bis(azanylylidene))bis(methanylylidene))bis(4-(phenyldiazenyl)phenol) $\left(\mathrm{M}_{17}\right)$ : m.p. $243^{\circ} \mathrm{C}-245^{\circ} \mathrm{C}$ dec., 40\%; IR $\left(\mathrm{KBr}, \mathrm{cm}^{-1}\right)$ : $3357(\mathrm{O}-\mathrm{H}), 3025(\mathrm{C}-\mathrm{H}$ aromatic), $1603(\mathrm{C}=\mathrm{N}), 1479(\mathrm{C}=\mathrm{C}$ aromatic), $1454(\mathrm{~N}=\mathrm{N}), 2853(\mathrm{C}-\mathrm{H}$ aliphat- 
ic). UV-vis (nm): 252, 348, 439.Anal. Calcd. $\left(\mathrm{C}_{46} \mathrm{H}_{36} \mathrm{~N}_{10} \mathrm{O}_{2}\right): \mathrm{C}, 72.62 ; \mathrm{H}, 4.77 ; \mathrm{N}$, 18.41. Found: C, 72.22; H, 5.40; N, 18.36 .

2,2'(((((1,4-phenylenebis(methanylylidene))bis(azanylylidene))bis(pyridine-6,2diyl))bis(azanylylidene))bis(methanylylidene))bis(4-((4-chlorophenyl)diazenyl) phenol) $\left(\mathrm{M}_{18}\right)$ : m.p. $207^{\circ} \mathrm{C}-209^{\circ} \mathrm{C}$ dec., 65\%; IR (KBr, cm $\left.{ }^{-1}\right): 3421(\mathrm{O}-\mathrm{H}), 3055$ (C-H aromatic), $1622(\mathrm{C}=\mathrm{N}), 1520(\mathrm{C}=\mathrm{C}$ aromatic), $1477(\mathrm{~N}=\mathrm{N}), 769(\mathrm{C}-\mathrm{Cl})$. UV-vis (nm): 252, 353, 448.

2,2'(((((1,4-phenylenebis(methanylylidene))bis(azanylylidene))bis(pyridine-6,2diyl))bis(azanylylidene))bis(methanylylidene))bis(4-((4-nitrophenyl)diazenyl) phenol) $\left(\mathrm{M}_{19}\right)$ m.p. $173^{\circ} \mathrm{C}-175^{\circ} \mathrm{C}$ dec., 55\%; IR (KBr, cm $\left.{ }^{-1}\right): 3379(\mathrm{O}-\mathrm{H}), 3050$ (C-H aromatic), $1606(\mathrm{C}=\mathrm{N}), 1525(\mathrm{C}=\mathrm{C}$ aromatic), $1450(\mathrm{~N}=\mathrm{N}), 1500-1357$ $\left(\mathrm{NO}_{2}\right) . \mathrm{UV}$-vis (nm): 232, 375, 519. ${ }^{1} \mathrm{H}-\mathrm{NMR}(\mathrm{DMSO}): \delta=8.11(\mathrm{~s}, 2 \mathrm{H}, \mathrm{CH}=\mathrm{N})$, 7.0 - 8.46 (m, $24 \mathrm{H}, \mathrm{Ar}-\mathrm{H}), 10.33$ (s, $2 \mathrm{H}, \mathrm{OH})$.

Sodium 4,4'-(((((1,4-phenylenebis(methanylylidene))bis(azanylylidene))pyridine-6, 2diyl))bis(azanylylidene))bis(methanylylidene))bis(4-hydroxy-3,1-phenylene))bi $\mathrm{s}\left(\right.$ diazene-2,1-diyl))dibenzenesulfonate $\left(\mathrm{M}_{20}\right)$ m.p. $191^{\circ} \mathrm{C}-193^{\circ} \mathrm{C}$ dec., $75 \%$; IR $\left(\mathrm{KBr}, \mathrm{cm}^{-1}\right): 3465(\mathrm{O}-\mathrm{H}), 3045(\mathrm{C}-\mathrm{H}$ aromatic), $1585(\mathrm{C}=\mathrm{N}), 1580(\mathrm{C}=\mathrm{C}$ aromatic), $1480(\mathrm{~N}=\mathrm{N}), 1198\left(\mathrm{SO}_{3}\right)$. UV-vis (nm): 251, 345, 429. ${ }^{1} \mathrm{H}-\mathrm{NMR}$ (DMSO): $\delta=8.11(\mathrm{~s}, 2 \mathrm{H}, \mathrm{CH}=\mathrm{N}), 7.7-8.11(\mathrm{~m}, 24, \mathrm{Ar}-\mathrm{H}), 10.31(\mathrm{~s}, 2 \mathrm{H}, \mathrm{OH})$.

\section{Results and Discussions}

Microwave radiation procedure were followed in the synthesis of tetra Schiff bases $\left(M_{2}-M_{10}\right)$ by condensation one milliequivalent of $\left(M_{1}\right)$ with two milliequivalent of different specific aldehydes, and in the synthesis of five new series of bis azo-bis Schiff bases $\left(M_{16}-M_{20}\right)$ through condensation reaction of the same ratios of milliequivalents of $\left(\mathrm{M}_{1}\right)$ with two milliequivalent of three well-known azo-salicyladehydes $\left(M_{11}, M_{12}, M_{14}\right)$ [23] [34] and two new ones $\left(M_{13}, M_{15}\right)$, as shown in (Scheme 1 and Scheme 2). However, the synthesis often suffers from low to moderate yields ranging from $42 \%$ to $75 \%$ besides difficulties in purification process.

The prepared compounds were characterized by different physicochemical techniques like melting point, elemental analysis, FTIR spectroscopy and multinuclear NMR $(1 \mathrm{H})$.

The ultraviolent-visible spectrophotometry technique is used to characterize the prepared compounds as $\left(1 \times 10^{-4}\right)$ solutions in DMSO as a solvent. The ultraviolet-visible electronic spectra of the prepared tetra Schiff bases showed absorption bands at the region $(243$ - 354) $\mathrm{nm}$, which could be attributed to the moderate $\pi-\pi^{\star}$ electronic transition of the aromatic ring [17]; these transitions are assigned in relevance to the structure of the compounds. The electronic spectrum of the prepared Schiff bases also show a band at the wavelength (287 310) $\mathrm{nm}$; this may attributed to the $(\mathrm{PhCH}=\mathrm{N}-)$ moiety of Schiff base overlapped with the lower $\pi-\pi^{*}$ electronic transition of the azomethine group [36]. This band was also assigned by some workers to charge transfer transition 


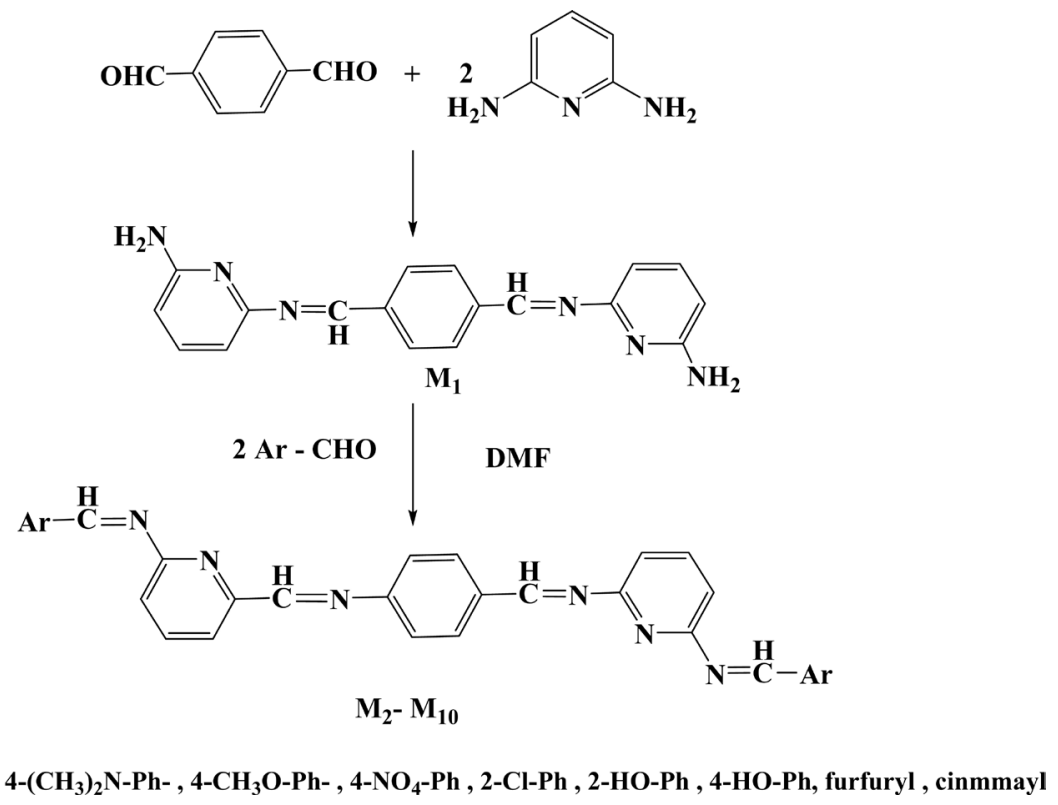

Scheme 1. The steps for tetraschiff-bases synthesis.

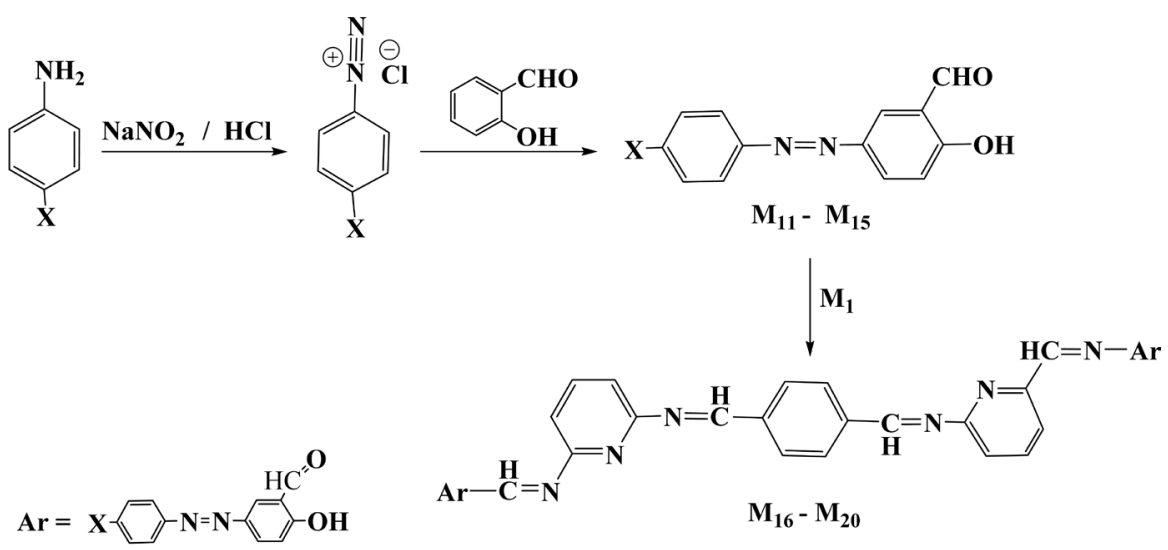

$\left(\mathrm{X}=\mathrm{H}, \mathrm{CH}_{3}, \mathrm{Cl}, \mathrm{NO}_{2}, 4-\mathrm{SO}_{4}\right)$

Scheme 2. The steps for azo-tetraschiff-bases synthesis.

resulted from (Phc) as donating group, and the azomethine group as the accepting one [35] [36] [37]. In the prepared Schiff bases, the bands shifted to longer wavelengths $(395$ - 420) nm, which may be attributed to both the bathochromic shifted $\pi-\pi^{*}$ transition due the effect of polar solvent (DMSO) and $n-\pi^{*}$ electronic transition of azomethine nitrogen atom [38]. The ultraviolet-visible electronic spectra of azo-Schiff bases $\left(\mathrm{M}_{16}-\mathrm{M}_{20}\right)$ showed almost the same patterns of absorption peaks in the regions $(232$ - 268) $\mathrm{nm}$, (345 - 375) $\mathrm{nm}$; whereas the third peak at (422 - 519) $\mathrm{nm}$ is attributed to $n-\pi^{\star}$ transition of nitrogen atoms of azo group. In the both cases (i.e. tetra Schiff and azo-Schiff cases) the characteristic absorption bands at $(218-225) \mathrm{nm}$, which is usually assigned to the local induction of (Phc) ring, was noted identified.

The band of $(\mathrm{C}=\mathrm{N})$ for imine stretching vibration was identified in the IR spectra of the prepared compounds. Shifting of this vibration were observed for 
tetra Schiff bases $\left(M_{2}-M_{10}\right)$ and assigned to the effect of the different substituents in the aromatic rings adjacent to the azomethine group, which were in the range (1589 - 1603) $\mathrm{cm}^{-1}$. The lower frequency is due to the effect of chloro substituent in the ortho position, and the higher frequency due to the presence of hydroxyl group at para position. For azo-Schiff bases this range observed at (1585 - 1622) $\mathrm{cm}^{-1}$, also the lower frequency is attributed to sodium sulfanate substituent in the para position and the higher frequency is thought to be resulted from the effect of chloro group at para position.

The ${ }^{1} \mathrm{H}$-NMR spectrums of compounds $\left(\mathrm{M}_{19}, \mathrm{M}_{20}\right)$ showed the following characteristic chemical shift (DMSO as a solvent): the singlet signal at $=8.11 \mathrm{ppm}$ suggested the attribution of the protons of azometine group, the multiplet signals at $=7.0-8.46 \mathrm{ppm}$ is attributed to the aromatic protons of two substituted pyridine rings and the five substituted benzene rings, whereas the singlet signal at $=10.31-10.33 \mathrm{ppm}$ is due to the two identical phenolic protons $(\mathrm{OH})$.

Azo compounds, in general, are colored compounds so they absorb light in the visible part of the solar spectrum; but their main problem is photoinstabilities, so we aimed to incorporate the energy rich azomethine group in the body of azo compounds so as to protect them from photodegradation by dissipating the solar radiation by photoisomerization and other photodissipation mechanisms [39] [40]. Moreover; this participation will serve in preparing new colored photosensitizers which may find their way to application in the well-known photochemical conversion systems [30]. This will be tested in the upcoming works, keeping in mind that there is a long way and severe challenges associated with this mission such as matching of oxidation potential of the prepared sensitizers and reduction potential of the relay systems.

\section{Conclusion}

The newly prepared, colored and thermally stable tetra-Schiff bases as well as azo-Schiff bases using microwave activation as environmentally friendly method-depending on our humble knowledge and experience-are candidates to be efficient absorbers in solar liquid collectors, and also as photosensitizers in Dye Sensitized Solar Cells (DSSC) to produce cost effective electricity or in four components systems to produce photo hydrogen fuel from aqueous mediums.

\section{Conflicts of Interest}

The authors declare no conflicts of interest regarding the publication of this paper.

\section{References}

[1] Bringmann, G., Dreyer, M., Faber, J.H., Dalsgaard, P.W. and Jaroszewski, J.W. (2004) Ancistrotanzanine C and Related 5,1'- and 7,3'-Coupled Naphthylisoquinoline Alkaloids from Ancistrocladus Tanzaniensis. Journal of Natural Product, 67, 743-748. https://doi.org/10.1021/np0340549 
[2] Salimon, J., Salih, N., Ibrahim, H. and Yousif, E. (2010) Synthesis of 2-N-Salicylidene-5-(substituted)-1,3,4-thiadiazole as Potential Antimicrobial Agents. Asian Journal of Chemistry, 22, 5289-5296.

[3] Guo, Z., Xing, R., Liu, S., Zhong, Z., Ji, X. and Wang, L. (2007) Antifungal Properties of Schiff Bases of Chitosan, N-Substituted Chitosan and Quanternized Chitosan. Carbohydrate Research, 342, 1329-1332. https://doi.org/10.1016/j.carres.2007.04.006

[4] Hania, M.M. (2009) Synthesis of Some Imines and Investigation of Their Biological Activity. E-Journal of Chemistry, 6, 629-637. https://doi.org/10.1155/2009/104058

[5] Tapabashi, N.O. (2016) Schiff Bases as Corrosion Inhibitors for Carbon Steel in HCl Solution. International Journal of Engineering and Advanced Research Technology, 2, 1-3.

[6] Mohammed, H.A. and Taha, N.I. (2017) Microwave Preparation and Spectroscopic Investigation of Binuclear Schiff Base Metal Complexes Derived from 2,6-Diaminopyridine with Salicylaldehyde. International Journal of Organic Chemistry, 7, 412-419. https://doi.org/10.4236/ijoc.2017.74033

[7] Tümer, M., Ekinci, D. and Tümer, F.A. (2007) Synthesis, Chracterization and Properties of Some Divalent Metal (II) Complexes: Their Electrochemical, Catalytic, Thermal and Antimicrobial Activity Studies. Spectrochimica Acta Part A: Molecular and Biomolecular Spectroscopy, 67, 916-921. https://doi.org/10.1016/j.saa.2006.09.009

[8] Mahmoud, M.J., Numan, A.T. and Al-Obaidi, O.B.M.S. (2013) Synthetic and Characterization of $\mathrm{New}$ Schiff Bases Complexes with $\mathrm{Co}^{\mathrm{II}}, \mathrm{Ni}^{\mathrm{II}}, \mathrm{Cu}^{\mathrm{II}}$ and $\mathrm{Pd}^{\mathrm{II}}$ Ions. Journal of Al-Nahrain University, 16, 28-36. https://doi.org/10.22401/JNUS.16.1.05

[9] Nayak, S., Gamez, P., Kozlevc'ar, B., Pevec, A., Roubeau, O., Dehnen, S. and Reedijik, J. (2011) Coordination Compounds from the Planar Tridentate Schiff-Base Ligand 2-Methoxy-6-((quinolin-8-ylimino)methyl)phenol (mqmpH) with Several Transition Metal Ions: Use of [Fe III (mqmp) $\left(\mathrm{CH}_{3} \mathrm{OH}\right) \mathrm{Cl}_{2}$ ] in the Catalytic Oxidation of Alkanes and Alkanes. Polyhedron, 29, 2291-2296. https://doi.org/10.1016/j.poly.2010.04.035

[10] Kailas, H.K., Sheetal, P.J., Anita, P. and Apoorva, H. (2016) Four Synthesis Methods of Schiff Base Ligands and Preparation of their Metal Complex with IR and Antimicrobial Investigation. World Journal of Pharmacy and Pharmaceutical Sciences, 5 , 1055-1063.

[11] Mirza-Aghayan, M., Ghassemzadeh, M., Hoseini, M. and Boloutchian, M. (2006) Microwave-Assisted Synthesis of the Tetradentate Schiff-Bases under Solvent-Free and Catalyst-Free Condition. Synthetic Communications, 33, 521-523. https://doi.org/10.1081/SCC-120015804

[12] Kulshrestha, A. and Baluja, S. (2010) Microwave Promoted Synthesis of Some Schiff Bases. Archives of Applied Science Research, 2, 221-224.

[13] Shntaif, A.H. and Rashid, Z.M. (2016) The Synthesis of Schiff Bases under Microwave Irradiation: Review. Journal of Chemical and Pharmaceutical Science, 9, 1066-1068.

[14] Rao, V.K., Reddy, S.S., Krishna, B.S., Naidu, K.R.M., Raju C.N. and Ghosh, S.K. (2010) Synthesis of Schiff's Base in Aqueous Medium: A Green Alternative Approach with Effective Mass Yield and High Reaction Rates. Green Chemistry Letters and Reviews, 3, 217-223. https://doi.org/10.1080/17518251003716550

[15] Oforka, N.C. and Mkpenie, V.N. (2003) A New Method of Synthesis of Azo Schiff Base Ligands with Azo and Azomethine Donors: Synthesis of N-4-Methoxy-benzy- 
lidene-2-(3-hydroxyphenylazo)-5-hydroxyaniline and Its Nickel (II) Complex. Chinese Journal of Chemistry, 25, 869-871. https://doi.org/10.1002/cjoc.200790159

[16] Dinçalp, H., Toker, F., Durucasu, I., Avcıbaşı, N. and İçli, S. (2007) New Thiophene-Based Azo Ligands Containing Azo Methine Group in the Main Chain for the Determination of Copper (II) İons. Dyes and Pigments, 75, 11-24. https://doi.org/10.1016/j.dyepig.2006.05.015

[17] Aslantaş, M., Kurtoğlu, N., Şahin, E. and Kurtoğlu, M. (2007) 4-[(E)-Phenyldiazeny]-2-[(E)-phenyl-iminomethyl]phenol. Acta Crystallographica Section E, 63, o3637. https://doi.org/10.1107/S1600536807036197

[18] İspir, E. (2009) The Synthesis, Characterization, Electrochemical Character, Catalytic and Antimicrobial Activity of Novel, Azo-Containing Schiff Bases and Their Metal Complexes. Dyes and Pigments, 82, 13-19. https://doi.org/10.1016/j.dyepig.2008.09.019

[19] Yahyazadeh, A. and Azimi, V. (2012) Synthesis of Some Unsymmetrical New Schiff Bases from Azo Dyes. European Chemical Bulletin, 2, 453-455.

[20] Nikpassand, M., Fekri, L.Z. and Sharafi, S. (2013) An Efficient and Green Synthesis of Novel Azo Schiff Base and Its Complex under Ultrasonic Irradiation. Oriental Journal of Chemistry, 29, 1041-1046. https://doi.org/10.13005/ojc/290326

[21] Helal, T.A., Abbas, G.J. and Mohammed, F.H. (2014) Synthesis and Identification of New 4-Amino Phenazone Derivatives Containing Azo Group. International Journal of Multidisciplinary Research and Development, 1, 41-45.

[22] Shreekanta, S.A., Venkatesh, T.V., Parameshwara, P.N. and Shoba, K.S. (2014) Electrosynthesis, Electrochemical Behaviour, Antibacterial and Antifungal Activity of Novel Azo-Schiff's Bases. Indian Journal of Applied Research, 4, 91-95.

[23] Khanmohammadi, H. and Darvishpour, M. (2009) New Azo Ligands Containing Azomethine Groups in the Pyridazine-Based Chain: Synthesis and Characterization. Dyes and Pigments, 81, 167-173. https://doi.org/10.1016/j.dyepig.2008.07.019

[24] Eissa, H.H. (2013) Synthesis and Characterization of New Azo-Schiff Bases and Study Biological Activity. Journal of Current research in Science, 1, 444-450.

[25] Fekri, M.H., Darvishpour, M., Khanmohammadi, H. and Rashidipour, M. (2013) Synthesis and Biological Activity of a New Schiff Base Ligand Pyridazine Based. Journal of Chemical Health Risks, 3, 63-68.

[26] Kumar, H. and Chaudhary, R.P. (2010) Pesticidal Studies of An Azo Based Hetercyclic Schiff Base and Its Transition Metal Complexes. Archives of Applied Science Research, 2, 407-413.

[27] Mahdi, R.T., Ali, A.M. and Noaman, H.A. (2014) Preparation and Characterization of Some Metal Complexes with New Heterocyclic Schiff-Azo Ligand. Journal of Al-Nahrain University, 17, 51-58. https://doi.org/10.22401/JNUS.17.4.08

[28] Al Hamdani, A.A.S., Balkhi, A., Falah, A. and Shaker, S.A. (2015) New Azo-Schiff Base Derived with Ni(II), Cu(II), Pd(II) and Pt(II) Complexes: Preparation, Spectroscopic Investigation, Structural Studies and Biological Activity. Journal of Chilean Chemical Society, 60, 2774-2785. https://doi.org/10.4067/S0717-97072015000100003

[29] Mehta, K.K. and Patel, A.D. (2016) Synthesis, Characterization, Biological and Chelating Properties of New Antipyrine Derived Azo Dyes and Its Transition Metal Complexes. Acta Chimica and Pharmaceutica Indica, 6, 26-31.

[30] Tapabashi, N.O., Al-Janabi, K.M. and Mohammed, S.A. (2017) Thermal Performance, Photostability and UV-Visible Spectroscopic Studies of Some Synthesized 
Azo-Schiff and Bis-azo-Schiff Bases. International Journal of Engineering and Advanced Research Technology, 3, 19-31.

[31] Li, G., Mark, M.F., Lv, H., McCamant, D.W. and Eisenberg, R. (2018) Rhodamine-Platinum Diimine Dithiolate Complex Dyads as Efficient and Robust Photosensitizers for Light-Driven Aqueous Proton Reduction to Hydrogen. Journal of American Chemical Society, 140, 2575-2586. https://doi.org/10.1021/jacs.7b11581

[32] Lewis, N.S. (2005) Chemical Control of Charge Transfer and Recombination at Semiconductor Photoelectrode Surfaces. Inorganic Chemistry, 44, 6900-6911. https://doi.org/10.1021/ic051118p

[33] Crabtree, G.W. and Lewis, N.S. (2007) Solar Energy Conversion. Physics Today, 60, 37-42. https://doi.org/10.1063/1.2718755

[34] Ayoob, M.M. (2016) Design, Synthesis and Spectroscopic Study of Some New Flavones Containing Two Azo Linkages. M.Sc. Thesis, Salahaddin University, Erbil.

[35] El-Bayoumi, M.A., El-Asser, M. and Abdel-Halim, F. (1971) Electronic Spectra and Structure of Schiff's Base. I. Benzanils. Journal of American Chemical Society, 93, 586-590. https://doi.org/10.1021/ja00732a004

[36] Saeed, A.A.H. (1979) Spectroscopic Evidence for the Presence of Mono- and Di-Protonated Species of $\mathrm{p}-\mathrm{N}, \mathrm{N}$-Dimethylaminobenzylideneaniline and Its p'-Substituted Derivatives. Indian Journal of Chemistry, 17, 105-107.

[37] Saeed, A.A.H. (1980) The Effect of Conjugation on the First Two Electronic Transition in Some P- and P'-Substituted Benzylideneaniline. Iraqi Journal of Chemistry, 21, 104-114.

[38] Patai, S. (1970) The Chemistry of the Carbon-Nitrogen Double Bond. John Wiley \& Sons Ltd., New York.

[39] Nief, O.A. (2013) Photostabilization of Poly (Vinyl Chloride) by Some Schiff Base Derived from 2-Amino Pyridine. Journal of Al-Nahrain University, 16, 18-28. https://doi.org/10.22401/JNUS.16.4.03

[40] Yousif, E., Al-Amiery, A.A., Kadihum, A., Kadhum, A.A. and Mohemad, A.B. (2015) Photostabilizing Efficiency of PVC in the Presence of Schiff Bases as Photostabilizers. Molecules, 20, 19886-19899. https://doi.org/10.3390/molecules201119665 